\title{
Implementation and Performance Analysis of a Switched Reluctance Motor Fed from Non- Energy Stored PV System
}

\author{
S. B. Efe, B. Kocaman and D. D. Aktaş
}

\begin{abstract}
In this paper, an actual system that consist of a switched reluctance motor (SRM) and photovoltaic (PV) generation was analyzed to determine operational behaviors in terms of both generating and motor units. System was designed without an energy storage unit. This type of design allows obtaining more convergence and actual results during operation in different conditions. According to this aim, a system that includes such structures was constructed physically. System was operated and observed for different weather and loading conditions. As the proposed system was aimed to use for agricultural electrical vehicle applications, results were discussed by using graphs that obtained from various points, especially in terms of these approaches.
\end{abstract}

Index Terms - Photovoltaic system, power system analysis, renewable energy sources, switched reluctance motor.

\section{INTRODUCTION}

$\mathrm{T}$ ECHNOLOGICAL DEVELOPMENTS increases the energy use in acceleration and the conventional energy sources cannot meet this demand. It became vital to integrate renewable energy sources to main grid for supplying quality and continuous energy to customers. One of the major loads in power systems are motor loads. As it is known that motor parameters are directly affect from supply parameters like voltage and current, in this study, a switched reluctance motor (SRM) that supplied by a photovoltaic (PV) system is analyzed during various operating conditions. It is aimed to obtain operational data to determine the motor efficiency while supplied by a renewable energy source. System was designed as not to include any storage unit like battery. This allows researchers to test the motor in limited supply capacity conditions and obtain more actual results. According to this aim, literature was reviewed for PV systems and motor applications. Studies on PV applications, which include design [1-3] and analysis [4-6] of such systems, can be observed

S. B. EFE, is with Department of Electrical and Electronics Engineering Bitlis Eren University, Bitlis, Turkey, (e-mail: sbefe@beu.edu.tr).

B. KOCAMAN, is with Department of Electrical and Electronics Engineering

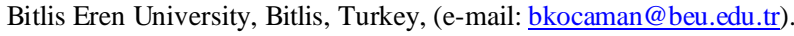

D. D. AKTAŞ, is MSc. student with Department of Electrical and Electronics Engineering Bitlis Eren University, Bitlis, Turkey, (e-mail: dilandemir08@gmail.com).

Manuscript received August 30, 2018; accepted October 28, 2018. DOI: $10.17694 /$ bajece. 455150 widely in literature. It is necessary to analyze the PV modules for energy output characteristics because of the mismatch losses and shading losses of such structures. PV system studies are divided into two in general as grid connected [7-8] and islanded or standalone [9-10] modes of operation. In addition, researchers are focused on the various types of motors as loads for PV systems. These papers are classified as induction motor [11-12] and DC motor [13-14] supplement. Besides the classical electric motors, in this research, SRM is chosen to use its advantages as given in following sections. The paper was designed as following; in section II mathematical models of system components, which are PV system and SRM, were given. Performance analysis was performed in section III and results were discussed in section IV.

\section{MATHEMATICAL BACKGROUND}

Mathematical representation of the system elements have to be given for a better understanding of performance analysis results besides physical structures. Therefore, mathematical models and actual system components of PV system and SRM are given in subsections A and B respectively.

\section{A. Photovoltaic System}

The PV effect is the creation of voltage or electric current in a material upon exposure to light. PV system works on the principle of photovoltaic effect, direct conversion of photonic energy to electrical energy using PV cells. The power generated from these PV cells depends directly on the level of solar irradiation [15].

Detailed analysis and study is necessary for an appropriate design of PV systems. Therefore, it should be started from cell level for better understanding. PV panels are formed by connecting photovoltaic cells series and parallel, which are created by semiconductor materials. General structure of a PV cell is given in Fig. 1. [16-18].

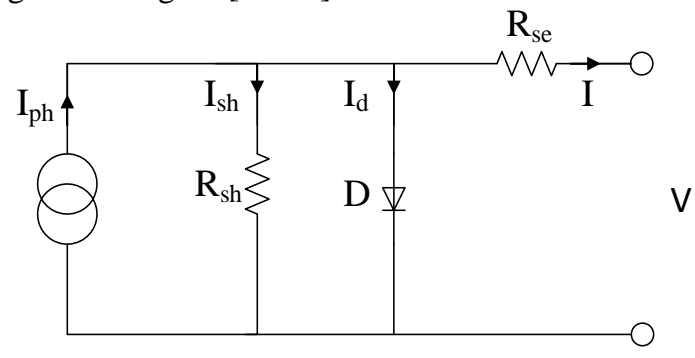

Fig. 1. PV cell circuit 
According to the given equivalent circuit, mathematical model of a PV cell can be described as:

$$
\begin{gathered}
I=I_{p h}-I_{d}-I_{s h} \\
I=I_{p h}-I\left[e^{q\left(V+I R_{s e}\right) / k T}-1\right]-\frac{V+I R_{s e}}{R_{s h}}
\end{gathered}
$$

In Equation (2), I shows the current, $\mathrm{V}$ represents the terminal voltage, $\mathrm{q}$ shows electron charge, $\mathrm{k}$ is the Boltzmann constant and $\mathrm{T}$ is the ambient temperature in terms of Kelvin. According to the design, Equation (2) can also be rewritten to obtain output voltage.

In this study, a PV system that is physically installed at Bitlis Eren University Rahva Campus is used as energy source for SRM. This structure is given in Fig. 2.

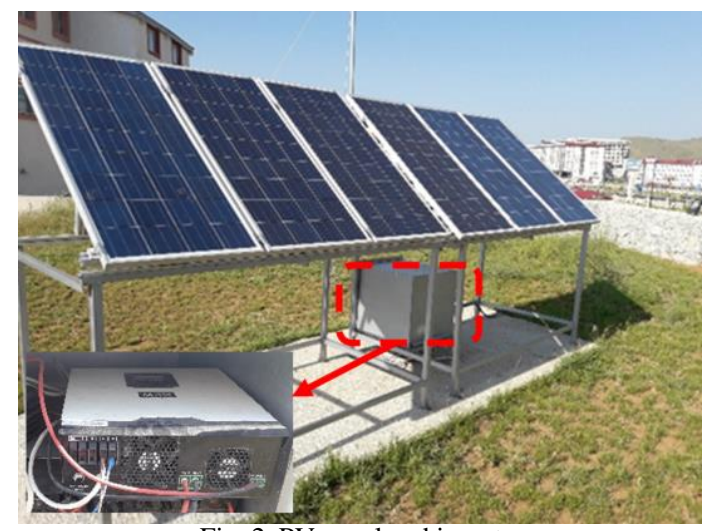

Fig. 2. PV panel and inverter

There were six PV panels, each has a power of $150 \mathrm{~W}$, and a $24 / 220 \mathrm{~V}$ full sine inverter with a power of $3000 \mathrm{VA}$ used for PV system.

\section{B. Switched Reluctance Motor}

SRM can be considered as an alternative to conventional electric machines. It is cheaper and simpler than the same powerful conventional machines because of the improvements in motor drive technology [19-20].

The equivalent circuit of SRM is shown in Fig.3. In this circuit, output emf can be modeled as a current controlled voltage source. Due to the saliency on rotor and stator side, SRM has non-sinusoidal current and flux across all windings.

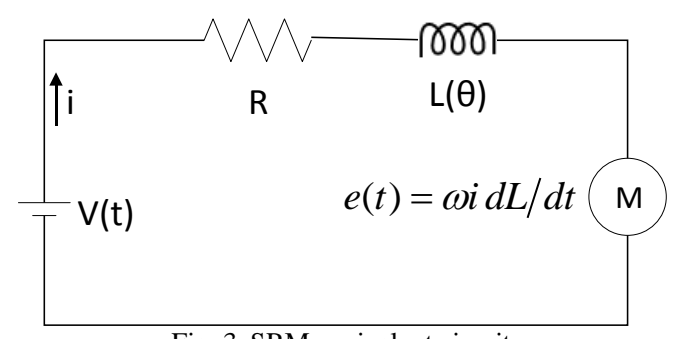

Fig. 3. SRM equivalent circuit

According to the Fig. 3, voltage equation for one phase can be given as,

$$
v=R i+\frac{d \psi}{d t}=R i+\frac{d(L i)}{d t}=R i+L \frac{d i}{d t}+i \frac{d L}{d t}
$$

$$
=R i+L \frac{d i}{d t}+i \frac{d L}{d \theta} \frac{d \theta}{d t}
$$

And finally

$$
v=R i+L \frac{d i}{d t}+\omega_{m} i \frac{d L}{d \theta}
$$

where $\mathrm{v}$ is terminal voltage, $\mathrm{R}$ is phase resistance, $\mathrm{i}$ is current, $\psi$ is flux, $\mathrm{L}$ is phase inductance, $\theta$ is rotor position and $\omega_{m}$ is angular speed in $\mathrm{rad} / \mathrm{s}$.

Power value can be obtained as

$$
P=V i=R i^{2}+L_{i} \frac{d i}{d t}+\omega i^{2} \frac{d L}{d \theta}
$$

As the torque equation is

$$
T=\frac{P}{\omega_{e}}
$$

Then the torque Te that can obtained from the motor

$$
T_{e}=\frac{1}{2} i^{2} \frac{d L(i, \theta)}{d \theta}
$$

Similar as other motors, for SRM, torque is limited by maximum allowed current, and speed by the available terminal voltage, which is illustrated in Fig. 4.

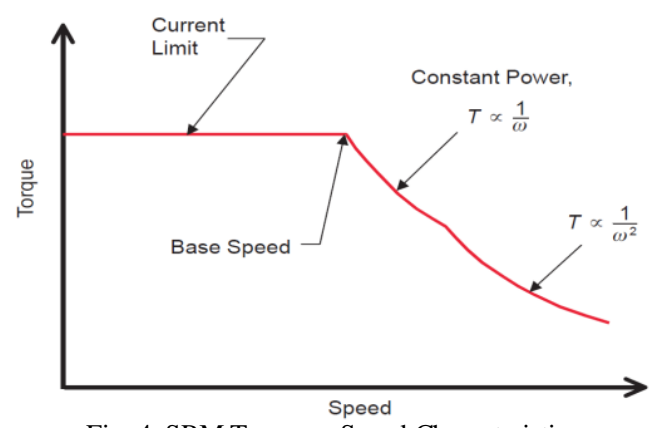

Fig. 4. SRM Torque - Speed Characteristics

Switched reluctance motor (SRM) has the advanced capability as it is the most suitable motor for variable speed applications like solar photovoltaic (SPV) array fed water pumping system. A PV pumping system using SRM is analyzed in [21-22] but it has some drawbacks due to use of battery [23]. The torquespeed operating point of an SRM is essentially programmable and determined almost entirely by the control. This is one of the features that makes the SRM an attractive solution for various applications [24].

An 8/6 SRM with an intelligent control unit was used in this study. SRM with intelligent control unit is shown in Fig. 5, where properties of the SRM that was used in system are summarized in Table 1.

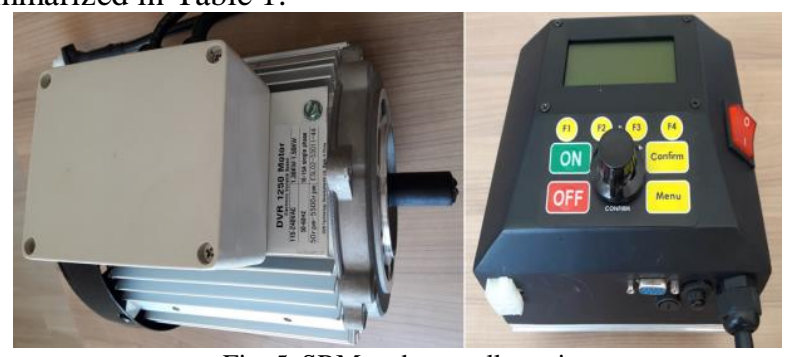

Fig. 5. SRM and controller unit 
TABLE I

SRM PROPERTIES

\begin{tabular}{|c|c|}
\hline Parameter & Value \\
\hline Phase & $1 \phi$ \\
\hline Nominal Voltage & $220 \mathrm{~V}$ \\
\hline Max. Power at Nom. Voltage & $1400 \mathrm{~W}$ \\
\hline Rotor Speed & 50 to $5000 \mathrm{rpm}$ \\
\hline
\end{tabular}

\section{EXPERIMENTAL PERFORMANCE ANALYSIS}

Proposed system was tested for different operating conditions to obtain performance data. Fluke 435 power and energy analyzer was used for measurement. As the system has no storage unit, PV generation directly affect the SRM. Therefore, system was observed in two cases, first was for different loading conditions in case of full irradiance and second in case of partial shading. A powder-brake unit with torque controller, which is shown in Fig. 6, was used to adjust loading values.

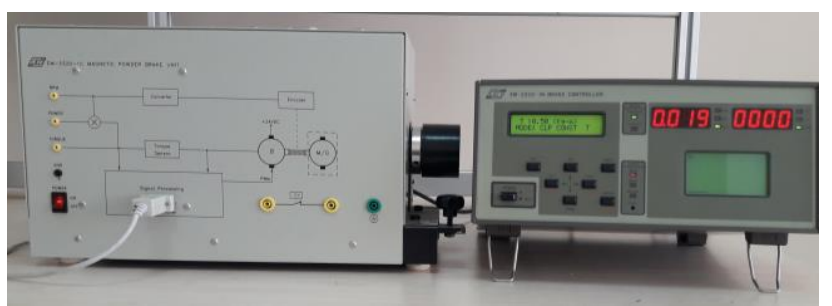

Fig. 6. Load unit

\section{A. Case 1-Nominal irradiance conditions}

In this case, system was tested when the PV had nominal irradiance. SRM was adjusted to operate at 1000 -rpm rotor speed, loaded with $15 \%, 30 \%, 45 \%$ and $60 \%$ respectively in such condition and results were summarized in Fig. 7.

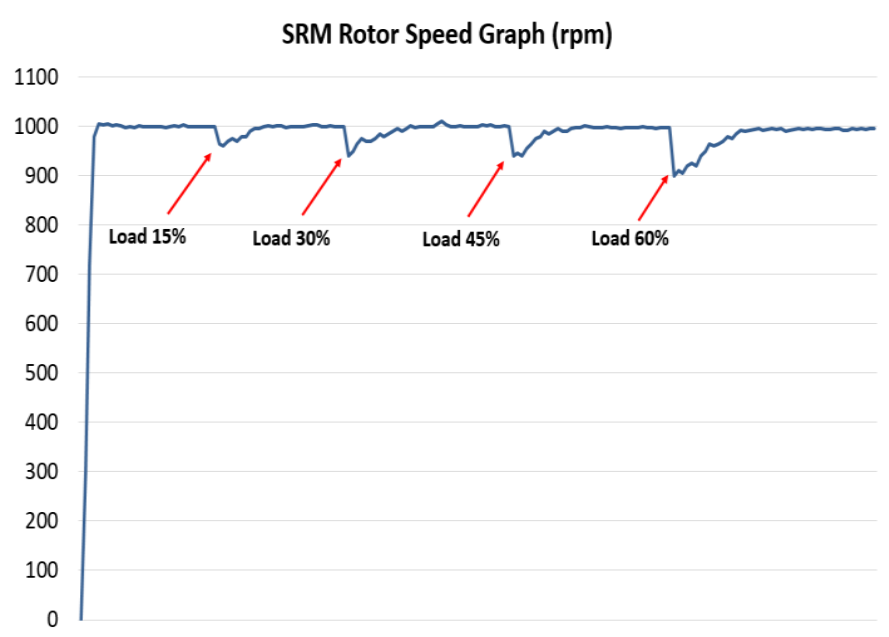

Fig. 7. Rotor speed during nominal irradiance

It is clear from Fig.7 that SRM could regulate the speed via intelligent control unit in nominal irradiance conditions. As there was a decrement in rotor speed, it was in tolerance limits that can be ignored. Therefore, it can be assumed that motor works efficiently under proposed conditions.

\section{B. Case 2- Partial shading conditions}

As it is common to occur irradiance decrement in case of possible shading at PV panels because of meteorological effects and dust, system was analyzed to obtain operational data for such conditions. In this case, irradiance was decreased $20 \%$ and $40 \%$ manually. Motor was loaded 15\%, 30\%, $45 \%$ and $60 \%$ for each level and results of $20 \%$ and $40 \%$ irradiance decrement were given in Fig. 8 and Fig. 9 respectively.

\section{SRM Rotor Speed Graph (rpm)}

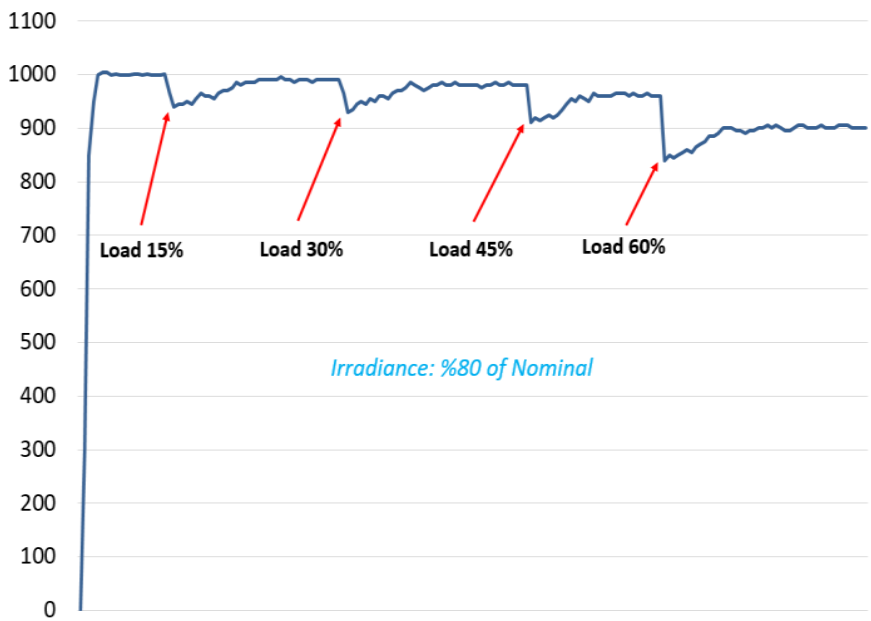

Fig. 8. Rotor speed during $80 \%$ of nominal irradiance

SRM Rotor Speed Graph (rpm)

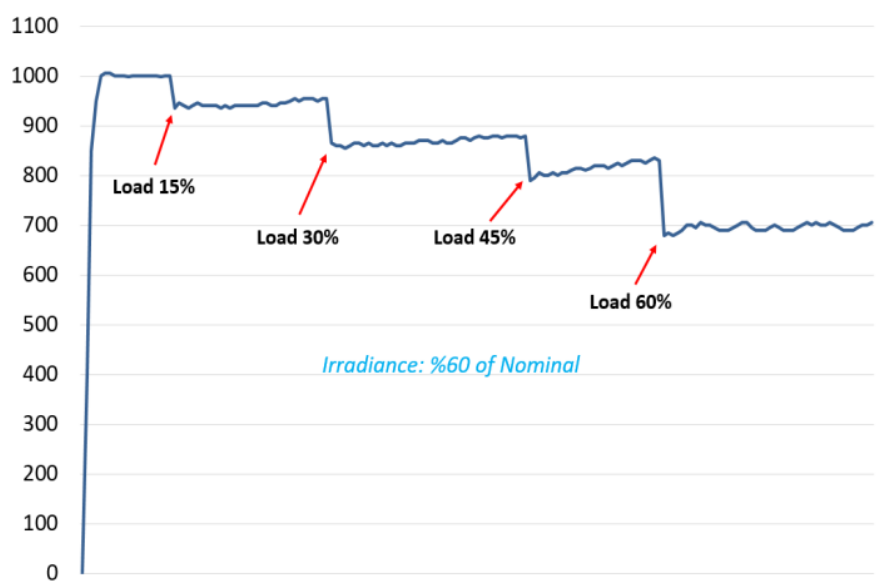

Fig. 9. Rotor speed during $60 \%$ of nominal irradiance

As irradiance is the major parameter of PV generation, it is clear from Fig. 8 and Fig. 9 that decrement in such parameter affect motor speed especially when loading value increased. Unlike the Case 1 results, as expected, motor speed cannot be recovered to nominal speed. However, it still continues to operate and shows stability in speed characteristic. Speed can be regulated by controlled load-shedding in case of generation level decrement by a closed loop algorithm.

\section{CONCLUSION}

In this study, a SRM is analyzed under different operating conditions to obtain the behaviors in case of renewable energy source based supplement. These behaviors are vital for agricultural applications and especially to use SRM in PV 
supplied electric cars. For such aim, system is analyzed for direct PV-fed mode of operation. Various loading and irradiance conditions are tested and results are discussed by using system graphs. It is clear that SRM is appropriate in using non-storage unit systems that have limited capacity of energy with an appropriate controlling unit. In case of decrement in generation values, motor speed can also be regulated by controlling loads. It should be noted that all meteorological effects are applied to experimental system and these affect results directly. Authors are in process of determine data for various conditions and applications.

\section{ACKNOWLEDGMENT}

This study is supported by Bitlis Eren University Scientific Research Projects Unit (BEBAP) with project number BEBAP 2018.06. Authors would like to thank BEBAP for valuable contribution.

\section{REFERENCES}

[1] J. Matics and G. Krost, "Intelligent Design of PV Based Home Supply Using a Versatile Simulation Tool," 13th International Conference on, Intelligent Systems Application to Power Systems, 2005, pp. 61-66.

[2] B. Ramkumar H.M. Kittur, and P. M. Kannan, "A Solid 500 Sun Compound Concentrator PV Design," IEEE 4th World Conference on Photovoltaic Energy Conference, 2006, pp.694-697.

[3] J. Xue, Z. Yin, B. Wu and J. Peng, "Design of PV Array Model Based On EMTDC/PSCAD," IEEE Asia-Pacific Power and Energy Engineering Conference, 2009, pp. 1-5.

[4] H. So, B. G. Yu, H. M. Hwang, G. Yu, Y. Choi and I. Choy, "Performance Monitoring and Analysis of Middle Scale GridConnected PV System," IEEE the 7th International Conference on Power Electronics, 2007, pp. 451-454.

[5] C.I. Wade, R. Torihara, Y. Fukamachi, T. Sakoda and N. Hayashi, "Numerical Analysis of I-V Characteristics and Diode Currents of a PV Module Reflected by Partial Shadow," IEEE Region 10 Conference (TENCON), 2016, pp. 2642-2645.

[6] F.E. Tahiri, K. Chikh, M. Khafallah, A. Saad and D. Breuil, "Modeling and performance analysis of a solar PV power system under irradiation and load variations," 14th International Multi-Conference on Systems, Signals \& Devices (SSD), 2017, pp. 234-238.

[7] T. K. Roy, M. F. Pervej, M. I. Sarkar, and F. K. Tumpa, 'Nonlinear Robust Controller Design for a Grid- Connected PV System Using DPC Approach," International Conference on Electrical, Computer and Communication Engineering (ECCE), 2017, pp. 11-16.

[8] R. Abdul Rahman, S. Irwan Sulaiman, A. Maliki Omar, S. Shaari and Z. Md Zain, "Performance Analysis of a Grid- connected PV System at Malaysian Energy Centre, Malaysia," The 4th International Power Engineering and Optimization Conference (PEOCO2010), 2010, pp. $480-483$.

[9] S. Choudhary, S. Saha, S. Jacob, S. Ikshith and M. Kher, "Reduction of Electricity Bill With Stand-Alone Solar PV System," International Conference on Nascent Technologies in the Engineering Field (ICNTE2017), 2017, pp. 1-5.

[10] W.Saed, H.A. Gaber and A. Mami, "Sizing and Simulation of an Energy Sufficient Stand-alone PV Pumping System," International Conference on Promising Electronic Technologies, 2017, pp. 8-13.

[11] K. Cherifi, Y. Miloud and M. Mostefai, "Performance of Five Level Inverter with Induction Motor Fed by PV Generator," 4th International Symposium on Environmental Friendly Energies and Applications (EFEA), 2016, pp. 1-5.

[12] S.S. Dessouky, A. A. Elbaset, A. H. K. Alaboudy, H. A. Ibrahim and S. A. M. Abdelwahab, "Performance Improvement of A PV-Powered Induction-Motor-Driven Water Pumping System," Eighteenth International Middle East Power Systems Conference (MEPCON), 2016, pp. 1-7.

[13] J.S. Kol, B.J. Jung, K.T. Park, C. H. Choi and D.H. Chung, "Maximum Power Point Tracking Control of PV System for DC Motors Drive with
Neural Network," International Conference on Smart Manufacturing Application, 2008, pp. 514-519.

[14] S. Krithiga, and N.A. Gounden, "A Microcontroller based Power Electronic Controller for PV assisted DC motor Control," 6th International Conference on Industrial and Information Systems, ICIIS 2011, 2011, pp. 505-510.

[15] M.R. Praful, A.M. Joshua, "Controller for Stand-Alone PV Systems", IEEE International Conference on Power, Control, Signals and Instrumentation Engineering (ICPCSI), 2017, pp.1012-1017.

[16] B. Kocaman, M. Akdağ, S.B. Efe, M. Akdeniz, "Implementation and Performance Analysis of a Hybrid PV-Wind Energy System", International Journal of Engineering and Advanced Technology, Vol.7 No.1, pp.100-104.

[17] S.B. Efe, M. Cebeci, "Artificial Neural Network Based Power Flow Analysis for Micro Grids", Bitlis Eren University Journal of Science and Technology, 2015, Vol.5, No.1, pp.42-47.

[18] S.B. Efe, M. Cebeci, H. Erdoğan, G. Öztürkmen, "A Novel Approach to Power Flow Analysis for Grid Connected Micro Grid", 13th ICEMES, 2015, pp.29-32.

[19] S.B. Efe, B. Kocaman, D. Demir Aktaş, "Operational Analysis of a Switched Reluctance Motor Fed by PV System”, IIER 2018, pp.56-59.

[20] D. Demir, S.B. Efe, "Analysis of PV Supplied SRM for Different Operating Conditions", ICAT'18, 2018, pp. 269-272.

[21] S. Belliwali, A.Chakravarti, A.B. Raju, "Mathematical modelling and simulation of directly coupled PV water pumping system employing Switched Reluctance Motor" IEEE PES Innovative Smart Grid Technologies, 2011, pp.386-390.

[22] H.M.B. Metwally, W.R. Anis, "Performance Analysis of PV Pumping Systems Using Switched Reluctance Motor Drives", Energy Conversion and Management, 1997, Vol.38, No.1, pp. 1-11.

[23] B. Singh, A.K. Mishra, R. Kumar, "Buck-boost converter fed SRM drive for solar PV array based water pumping", IEEE IAS Joint Industrial and Commercial Power Systems / Petroleum and Chemical Industry Conference, 2015, pp.153-160.

[24] M.T. DiRenzo, "Switched Reluctance Motor Control - Basic Operation and Example Using the TMS320F240", 2000, Texas Instruments Application Report.

\section{BIOGR APHIES}

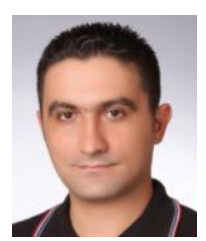

SERHAT BERAT EFE was born in Diyarbakır, in 1979. He received the B.S. degree in Electrical and Electronics Engineering from Dicle University, (Turkey), in 2003, the M.S. degree in Electrical and Electronics Engineering from İnönü University, (Turkey), in 2007 and the Ph.D. degree Electrical and Electronics Engineering from Firat University, (Turkey), in 2014. Since 2014, he has been an Assistant Professor with the Electrical and Electronics Engineering department, Bitlis Eren University, (Turkey). His main research areas are power system analysis, power quality and renewable energy sources.

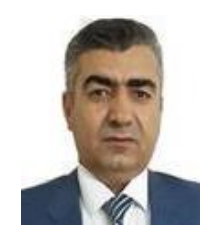

BEHÇET KOCAMAN was born in Bitlis, in 1972. He received the B.S. degree in Electrical Engineering from Yildız Technical University, (Turkey), in 1993, the M.S. and $\mathrm{PhD}$ degrees in Electrical Engineering from Kocaeli University, (Turkey), in 1997 and 2015 respectively. Since 2015, he has been an Assistant Professor with the Electrical and Electronics Engineering department, Bitlis Eren University, (Turkey).

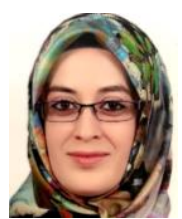

DÍLAN DEMİR AKTAS was born in Bitlis, in 1991. She received the B.S. degree in Electrical and Electronics Engineering from Furat University (Turkey) in 2014. Since 2016, she has been a M.S. degree student with the Electrical and Electronics Engineering department, Bitlis Eren University (Turkey). 